\title{
Penguatan Kelembagaan Kelurahan Pasca Implementasi UU No. 23 Tahun 2014 tentang Pemerintahan Daerah
}

\author{
Strengthening Institution of 'Kelurahan' After Implementation of the Law \\ of No. 23/2014 On Local Governance
}

\author{
Bambang Tri Harsanto, Slamet Rosyadi, Wahyuningrat, Simin \\ Jurusan Ilmu Administrasi Negara Fakultas Ilmu Sosial dan Ilmu Politik \\ Universitas Jenderal Soedirman Purwokerto \\ Jlalan HR Boenyamin No.708, Grendeng, Purwokerto Utara, Kabupaten Banyumas, Jawa \\ Tengah 53122. Telepon: (0281) 635292 \\ E-mail: btriharsanto@yahoo.co.id
}

\begin{abstract}
The reduction of kelurahan (Sub-District Government) authority has decreased its duties and functions after the implementation of the Law No. 23/2014 on Local Governance. This policy stimulates several kelurahan at Wonosobo Region to propose their villages'status changing from kelurahan into desa (Rural Government). Based on this case, this research aims to analyze the actual performance of kelurahan, and the motives of the village status changing. This research uses descriptive qualitative approach to answer those objectives. Observation, in-depth interview and focus group discussion are used to obtain data from informants who represent kelurahan, local government, non-government organizations and community leaders. Technique of data analysis of this research uses interactive data analysis including collecting, condensing, and describing data which is ended by conclusion. Results of study show that although the main function and tasks of kelurahan has decreased significantly, in general, the performance in service area still satisfies the public. However, services for development of public facilities are still far from public expectation. Furthermore, this research also found that there are 4 aspects encouraging the kelurahan to change into desa, namely economic, political, geographical and community profile motives. Implication of this research leads to the need of strengthening of kelurahan particularly in developing physical facilities provision service. It is intended to anticipate the possibility of kelurahan which will be left behind by desa.
\end{abstract}

Keywords: kelurahan strenghthening, kelurahan performance, motive of changing

\begin{abstract}
Abstrak
Menyusutnya kewenangan kelurahan berdampak pada semakin berkurangnya tugas pokok dan fungsi kelurahan. Fenomena tersebut telah mendorong beberapa kelurahan di Kabupaten Wonosobo mengusulkan perubahan status dari kelurahan menjadi desa. Berangkat dari kasus tersebut, penelitian ini bertujuan: (1) menganalisis kinerja aktual kelurahan dan (2) menganalisis motif-motif perubahan status kelurahan menjadi desa. Untuk mengkaji kasus tersebut, penelitian ini menggunakan pendekatan kualitatif deskriptif. Data dikumpulkan melalui observasi, wawancara dan focus group discussion dengan informan terpilih yang mewakili unsur kelurahan, pemerintah daerah, dan lembaga kemasyarakatan. Data dianalisis dengan mengikuti teknik analisis data interaktif yang meliputi pengumpulan data, kondensasi data, tampilan data dan penarikan kesimpulan. Hasil penelitian menunjukkan bahwa meskipun tugas pokok dan fungsi kelurahan telah berkurang, secara umum layanan pemerintahan memuaskan masyarakat. Namun demikian, dari sisi pelaksanaan pembangunan fisik masih menunjukkan kinerja yang buruk. Lebih jauh, penelitian menemukan 4 motif yang menjadi alasan kelurahan ingin menjadi desa yaitu motif ekonomi, motif politis, letak geografis dan profil masyarakat. Implikasi dari penelitian ini adalah perlunya penguatan kelurahan yang masih berkarakter desa terutama untuk peningkatan pelayanan pembangunan fisik sehingga dinamika kelurahan tidak tertinggal dengan desa.
\end{abstract}

Kata kunci: penguatan kelurahan, kinerja kelurahan, motif perubahan

\section{Pendahuluan}

Penguatan kelembagaan dapat diperkuat melalui desentralisasi kewenangan yang diberikan kepada pemerintahan lokal. Transfer kewenangan dari pusat ke pemerintahan lokal akan membuka ruang terbuka kepada pemerintah lokal dan masyarakat dalam merumuskan kebijakan dan program pembangunan yang adaptif dengan kebutuhan lokal. Dengan desentralisasi proses pembelajaran sosial dan pertukaran pengalaman diantara para pemangku kepentingan dapat mendukung pengembangan kapasitas institusi lokal, keahlian aktor dan lembaga lokal, serta jejaring sosial (Sanginga et al. 2010). Secara akademik, desentralisasi pembangunan di tingkat lokal telah lama didukung oleh hasil hasil 
pengujian empirik. Menurut Johan van Zyil et al. (1995:6), desentralisasi pembangunan di tingkat lokal dapat memperluas manfaat pembangunan di wilayah pedesaan khususnya untuk meningkatkan pertumbuhan ekonomi populasi masyarakat miskin yang sebagian besar tinggal di wilayah pedesaan. Disamping perluasaan manfaat ekonomi, desentralisasi pembangunan desa juga diharapkan dapat meningkatkan kualitas layanan publik, akuntabilitas dan responsivitas pemerintahan desa, dan penguatan kapasitas lembaga lokal (Boasiako 2010, Ribot 2002).

Namun demikian, dalam tataran empirik desentralisasi pembangunan desa kepada pemerintah desa mengalami beberapa implikasi diantaranya kasus yang terjadi di Kabupaten Wonosobo dimana beberapa kelurahan berkeinginan kuat menjadi desa kembali. Berdasarkan identifikasi atas sejumlah studi ditemukan masalah-masalah paling mengemuka dalam proses pembangunan yang didesentralisasikan. Tang \& Nuhe (2016) menguji sikap-sikap yang berkembang pasca desentralisasi. Mereka menemukan bahwa desentralisasi dapat memupuk kepercayaan di berbagai level pemerintah namun tidak terhadap sikap pemerintahan yang otoriter. Roberto Ezcurra (2015) menguji dampak desentralisasi terhadap konflik masyarakat. Hasilnya, devolusi kekuasaan di tingkat subnasional dapat mengurangi konflik masyarakat sipil. Garcia et al. (2010) menguji penguatan demokrasi pasca desentraliasi. Mereka menemukan manfaat desentralisasi hanya dinikmati oleh penduduk yang tinggal dekat dengan pusat pemerintahan dan pasar. Lessmann (2009) menguji manfaat dan kerugian desentralisasi baik secara ekonomi maupun politik. Temuannya menunjukkan desentralisasi yang semakin besar telah menciptakan kesenjangan wilayah yang semakin kecil dan dan manfaat bagi daerah miskin.

Berdasarkan penelusuran pustaka terungkap bahwa kebijakan desentralisasi sebenarnya membawa implikasi positif seperti penguatan demokrasi maupun pengurangan kesenjangan wilayah. Namun demikian, ada pula dampak negatifnya yaitu tidak dapat menjangkau penduduk yang tinggal jauh dari pusat pemerintahan dan pasar. Yang menarik adalah studi-studi sebelumnya belum satupun yang menyoroti dampak desentralisasi di level pedesaan terhadap level pemerintahan yang setara dengan desa seperti kelurahan dalam konteks Indonesia. Kasus empirik ini menjadi semakin menarik ketika kebijakan dana desa memberikan manfaat ekonomi dan politik yang besar terhadap desa, namun tidak diikuti dengan penguatan lembaga kelurahan. Dengan demikian, studi yang diajukan ini memiliki tingkat kebaharuan yang tinggi untuk memberikan penjelasan terhadap dampak desentralisasi dan penguatan kelembagaan.

Sebagai dampak implementasi Undang Nomor 23 tahun 2014 tentang Pemerintahan Daerah terjadi upaya perampingan struktur organisasi pemerintah. Salah satunya dapat dilihat dari perubahan kedudukan kelurahan. Konsekuensinya, kelurahan tidak lagi sebagai perangkat daerah. Pendelegasian wewenang secara administratif dan politik dari kabupaten/kota kepada kelurahan pun berubah. Kelurahan merupakan street level bureaucrat yang bertanggungjawab memberikan pelayanan secara langsung kepada masyarakat. Padahal kelurahan idealnya memiliki kewenangan yang jelas dan luas guna meningkatkan kinerja khususnya dalam melayani masyarakat.

Status kelurahan yang bukan lagi sebagai perangkat daerah berarti pemerintah (termasuk kabupaten/ kota) tidak lagi mendesentralisasikan kewenangannya kepada kelurahan. Fungsi kelurahan sebagai instansi yang memiliki kewenangan mengorganisasikan masyarakat juga sudah tidak ada lagi. Dengan demikian, pemerintah daerah perlu menyikapi kondisi tersebut supaya tugas pelayanan kepada masyarakat pada level kelurahan tidak mengalami hambatan. Berbagai persoalan menyangkut kedudukan kelurahan pasca implementasi UU No. 23 Tahun 2016 tentang Pemerintahan Daerah terjadi di Kabupaten Wonosobo. Bahkan di Kabupaten Wonosobo telah muncul permohonan dari beberapa kelurahan untuk melakukan upaya perubahan status dari kelurahan menjadi desa. Kondisi tersebut didorong oleh tuntutan masyarakat yang semakin tinggi akan penyelenggaraan pelayanan publik dan pembangunan wilayah yang lebih baik. Melalui kajian kelurahan, studi ini mencoba untuk menganalisis kinerja aktual kelurahan pasca UU No 23 Tahun 2016 dan motif-motif yang mendorong usulan perubahan kelembagaan kelurahan. Munculnya permohonan dari beberapa kelurahan untuk melakukan upaya perubahan status dari kelurahan menjadi desa menjadi fenomena 
unik yang perlu mendapatkan perhatian agar desentralisasi tidak membawa dampak negatif terhadap penyelenggaraan pelayanan publik (Anonim 2015). Berdasarkan permasalahan tersebut, maka tujuan penelitian ini adalah untuk menganalisis kinerja aktual kelurahan dan motif yang menggerakkan beberapa kelurahan ingin mengubah statusnya menjadi desa.

\section{Metode Penelitian}

Penelitian dilaksanakan pada Juni sampai dengan November 2016 di Kelurahan Wonoroto, Wadaslintang dan Leksono Kabupaten Wonosobo. Sesuai dengan tujuan penelitiannya, pendekatan kualitatif digunakan untuk menjawab fokus penelitian mengenai deskripsi kinerja kelurahan pasca disahkannya UU No. 23 Tahun 2014 tentang Pemerintahan Daerah dan motif perubahan status kelurahan menjadi desa. Informan dipilih secara purposif yaitu 3 orang kepala kelurahan yang menjadi lokasi penelitian, 3 orang kepala Lembaga Pemberdayan Masyarakat Kelurahan (LPMK), 3 orang tokoh masyarakat dari tiap kelurahan, 3 orang camat dimana lokasi kelurahan berada, dan Kepala Bagian Pemerintahan Sekretariat Daerah Kabupaten Wonosobo. Data dikumpulkan dengan observasi, wawancara mendalam dan focus group discussion. Analisis data dilakukan dengan menggunakan model interaktif (Milles et al. 2014). Analisis interaktif diawali dengan pengumpulan data yang dibutuhkan. Kemudian data dikategorisasi sesuai dengan fokus penelitian. Selanjutnya, data ditampilkan dalam bentuk narasi untuk menjadi dasar penarikan kesimpulan. Dalam setiap tahapan analisis dimungkinkan untuk kembali ke proses tahap sebelumnya apabila data dipandang belum menjawab permasalahan yang diteliti. Bahkan dimungkinkan peneliti bisa kembali ke lapangan untuk mengumpulkan kekurangan atau memverifikasi data yang diperoleh. Untuk menguji validitas data yang diperoleh dilakukan triangulasi sumber data.

\section{Hasil Penelitian dan Pembahasan}

\section{Kinerja aktual kelurahan}

Kinerja secara teori dapat digambarkan sebagai hasil kerja suatu organisasi. Salah satu dimensi yang sangat penting dalam mengukur kinerja organisasi adalah capaian output serta efektivitas pelaksanaaan kegiatan organisasi. Oleh sebab itu, kinerja kelurahan merupakan hasil capaian kerja yang telah dilaksanakan oleh organisasi kelurahan berdasarkan tugas dan fungsinya sebagai satuan kerja pemerintah daerah. Pengukuran kinerja kelurahan dilakukan dengan melihat output hasil kerja kelurahan berdasarkan tupoksinya.

Tabel 1.

Pengukuran kinerja kelurahan

\begin{tabular}{|c|c|c|}
\hline No. & Kategori Layanan & Jenis Aktivitas \\
\hline 1. & Layanan Pemerintahan & $\begin{array}{l}\text { 1. Legalisasi layanan publik } \\
\text { 1. Layanan barang dan jasa } \\
\text { 2. Penyusunan rencana kerja Kelurahan } \\
\text { 3. Serapan Anggaran } \\
\text { 4. Penyusunan LAKIP }\end{array}$ \\
\hline 2. & Layanan Pubik & $\begin{array}{l}\text { 1. Layanan Administrasi kependudukan dan } \\
\text { 2. Lencatatan sipil } \\
\text { 2. Layanan Pembayaran PBB } \\
\text { 3. Layanan Trantibum }\end{array}$ \\
\hline 3. & Layanan Pembangunan & $\begin{array}{l}\text { 1. Pelibatan masyarakat dalam perencanaan } \\
\text { pembangunan } \\
\text { 2. Pelibatan masyarakat dalam pelaksanaan } \\
\text { pembangunan } \\
\text { 3. Pelibatan masyarakat dalam pemanfaatan dan } \\
\text { pengawasan pembangunan }\end{array}$ \\
\hline
\end{tabular}

Sumber : Diadopsi dari berbagai sumber, Tahun 2016 
Adapun fungsi kelurahan berdasarkan kewenangannya adalah: a) pelaksanaan kegiatan pemerintahan kelurahan; b) pemberdayaan masyarakat; c) pelayanan masyarakat; d) penyelenggaraan ketenteraman dan ketertiban umum; e) pemeliharaan prasarana dan fasilitas pelayanan umum; f) pembinaan lembaga kemasyarakatan. Dari keenam fungsi kelurahan tersebut, kinerja kelurahan dapat diukur melalui 3 kategori sebagaimana tabel 1.

Berikut ini diuraikan deskripsi kinerja aktual kelurahan berdasarkan kategori layanan yang diselenggarakan sebagai berikut.

Kinerja layanan pemerintahan lembaga kelurahan diukur dari aktivitas layanan: (1) Legalisasi layanan publik; (2) Layanan barang dan jasa; (3) Penyusunan rencana kerja Kelurahan; (4) Serapan Anggaran; (5) Penyusunan LAKIP. Dari hasil pengamatan menunjukkan bahwa secara umum layanan pemerintahan kelurahan telah dilakukan secara baik. Data dokumentasi menunjukkan bahwa layanan legislasi layanan publik seperti pengesahan surat pengantar pengurusan KTP, KK dan sejenisnya telah dilakukan sesuai prosedur dengan ketepatan waktu layanan dan biaya yang dikeluarkan telah sesuai dengan SOP yang ditetapkan. Hasil wawancara dengan tokoh masyarakat secara umum menyebutkan bahwa layanan yang diberikan oleh aparat kelurahan cukup memuaskan.

Pemberian layanan barang dan jasa seperti pembagian raskin, fasilitasi kegiatan sosial masyarakat telah dijalankan secara baik tanpa mendapat keluhan dari warga secara berarti. Dari hasil wawancara dan bukti dokumentasi aktivitas penyusunan rencana kerja kelurahan telah dilakukan dengan baik. Demikian pula tingkat penyerapan anggaran telah mencapai seratus persen, namun dari sisi laporan pertanggungjawaban dalam bentuk Laporan Akuntabilitas Kinerja Instansi Pemerintah (LAKIP) tidak pernah dilakukan.

Kinerja layanan publik yang dilakukan oleh lembaga kelurahan diukur dari aktivitas layanan: (1) Layanan Administrasi kependudukan dan pencatatan sipil, (2) Layanan Pembayaran PBB dan (3) Layanan ketentraman dan ketertiban umum (Trantibum). Dari hasil observasi diketahui bahwa layanan administrasi kependudukan dan catatan sipil telah berjalan dengan baik. Masyarakat memberikan apresiasi yang positif kepada aparat kelurahan berkaitan dengan layanan pengantar pengurusan KTP dan Pembuatan akte Kelahiran. Dalam hal layanan pembayaran PBB aparat kelurahan menggunakan strategi jemput bola, aparat yang mendatangi masyarakat yang akan membayar PBB sehingga masyarakat merasa terbantukan dan merasa lebih mudah dalam kegiatan pembayaran PBB. Dalam aktivitas trantibum aparat kelurahan juga telah melaksanakan dengan cukup baik, setiap ada kegiatan keramaian baik yang diselenggarakan secara umum (oleh pihak kelurahan maupun ormas) maupun yang diselenggarakan oleh individu seperti kegiatan hajatan, pihak kelurahan selalu menugaskan kepada tenaga keamanan kelurahan (Hansip) untuk menjaga, mengatur dan memantau jalannya kegiatan di lingkungan kelurahan. Layanan yang diberikan tersebut telah memberikan perasaan aman bagi masyarakat sehingga masyarakat tidak pernah mersa khawatir apabila di wilayahnya ada kegiatan keramaian yang mengundang masa yang banyak. Berdasarkan fakta-fakta di atas dapat disimpulkan bahwa kegiatan layanan publik yang dilakukan lembaga kelurahan telah menunjukkan kinerja yang baik.

Kinerja layanan pembangunan yang dilakukan oleh lembaga kelurahan diukur dari aktivitas layanan yaitu: (1) Pelibatan masyarakat dalam perencanaan pembangunan, (2) Pelibatan masyarakat dalam pelaksanaan pembangunan, (3) Pelibatan masyarakat dalam pemanfaatan dan pengawasan pembangunan. Hasil wawancara dengan sejumlah tokoh masyarakat menunjukkan bahwa pelibatan masyarakat dalam kegiatan perencanaan pembangunan belum berjalan dengan baik. Kegiatan Musrenbang memang telah berjalan, namun baru sebatas pada tataran formal. Kegiatan dilakukan karena tuntutan pertanggungjawaban administrasi semata. Dari sisi pelaksanaan pembangunan, kinerja aparat kelurahan masih menunjukkan kinerja yang rendah. Penyediaan fasilitas umum dan sosial di lingkungan kelurahan belum dapat memenuhi kebutuhan dari masyarakat. Pembangunan sarana dan prasarana wilayah seperti jalan lingkungan, rambu-rambu lalu lintas sangat tidak memadahi. Peran lembaga kelurahan dalam penyediaan utilitas seperti penyediaan jarungan air 
bersih, listrik dan komunikasi juga sangat kurang. Dari aktivitas layanan bidang pembangunan yang diberikan menunjukkan bahwa kinerja layanan aparatur kelurahan pada bidang pembangunan fisik masih menunjukkan kinerja yang buruk.

Berdasarkan analisis kinerja kelurahan diketahui beberapa faktor penyebab masih belum optimalnya kinerja kelurahan yang ada di Kabupaten Wonosobo. Berdasarkan hasil wawancara dan diskusi kelompok terfokus terungkap beberapa faktor yang menyebabkan belum optimalnya kinerja kelurahan.

\section{Kewenangan}

Kelurahan menjalankan tugas pokok dan fungsinya berdasarkan Peraturan Bupati Nomor 67 Tahun 2014 tentang Tugas Pokok, Fungsi, Rincian dan Tata Kerja Kelurahan Kabupaten Wonosobo. Dalam kebijakan tersebut telah dijelaskan tentang tugas dan tanggungjawab yang harus dilaksanakan oleh kelurahan. Kelurahan mempunyai tugas pokok penyelenggaraan pemerintahan, pembangunan, dan kemasyarakatan di tingkat kelurahan berdasarkan kewenangan yang dilimpahkan oleh Bupati untuk menangani sebagian urusan otonomi daerah, dalam rangka terwujudnya pelayanan prima dan tata kelola pemerintahan di kelurahan secara efisien, efektif, dan akuntabel. Namun demikian berdasarkan hasil FGD diperoleh informasi bahwa kelurahan masih membutuhkan kewenangan yang lebih besar guna menjalankan tugas pokok fungsinya lebih baik. Secara teori, kewenangan adalah hak yang diperoleh sebuah unit organisasi dalam rangka pelaksanaan tugas yang diberikan. Oleh sebab itu, tanpa kewenangan yang optimal, tugas dan fungsi kelurahan tidak akan berjalan secara efektif.

Beberapa kelurahan di Kabupaten Wonosobo masih belum mampu menghasilkan kinerja kelurahan yang optimal. Hal tersebut disebabkan kewenangan yang diberikan oleh bupati belum mampu mendukung peningkatan kapasitas kelurahan sebagai fungsi pelaksana sebagian tugas otonomi daerah. Beberapa hasil kinerja seperti pelayanan publik, pemberdayaan masyarakat, administrasi pemerintahan belum berjalan efektif. Kewenangan yang dimaksud dalam konteks penyelenggaraan kegiatan di kelurahan adalah bahwa kelurahan diberikan hak untuk membuat berbagai kebijakan sesuai kebutuhan masyarakat, mengelola pendapatan dan sumber daya manusia.

\section{Anggaran}

Persoalan anggaran menjadi faktor yang juga sangat menentukan kinerja organisasi. Anggaran diibaratkan seperti aliran darah dalam tubuh manusia. Tanpa anggaran pelaksanaan tugas dan fungsi organisasi tidak akan dapat berjalan dengan optimal. Berdasarkan hasil FGD, anggaran menjadi persoalan penting yang menyebabkan masih belum optimalnya kinerja kelurahan. Berdasarkan hasil wawancara diketahui bahwa kelurahan masih merasakan anggaran yang diterima jauh dari memadai baik dari sisi jumlah dan kesesuaian. Meskipun kelurahan telah mendapatkan alokasi anggaran yang meningkat di setiap tahun, namun dari aspek kesesuaian dengan kebutuhan ternyata beberapa kegiatan yang dilaksanakan di Kelurahan tidak sesuai dengan kebutuhan masyarakat. Apabila dilihat dari anggaran program dan kegiatan yang dialokasikan kepada kelurahan cenderung seragam antara satu kelurahan dengan kelurahan lainnya. Fenomena ini memberikan gambaran bahwa kelurahan memang tidak memiliki keleluasaan dalam menentukan program dan kegiatan yang sesuai dengan kebutuhan masing-masing kelurahan. Hal tersebut menyebabkan banyak kelurahan yang tidak optimal dalam menyelesaikan persoalan riil yang terjadi di masyarakat. Selama ini proses musrembang hanya berjalan secara formalitas karena usulan kegiatannya seringkali tidak diakomodasi oleh pemerintah kabupaten.

\section{Sumber Daya Manusia}

Keberhasilan penyelenggaraan tugas dan fungsi organisasi juga berkaitan dengan ketersediaan sumberdaya manusia. Ketersediaan sumberdaya manusia baik secara kualitas maupun kuantitas 
akan menentukan kinerja organisasi, dalam hal ini adalah kelurahan. Sumber daya manusia yang dimaksud dalam kajian ini adalah aparatur kelurahan.

Permasalahan yang dihadapi oleh kelurahan dalam menghasilkan kinerja yang optimal adalah masih kurangnya kemampuan personel aparatur kelurahan dalam melaksanakan tugas yang dibebankan. Berdasarkan hasil diskusi kelompok terfokus ditemukan bahwa di beberapa kelurahan telah terjadi ketidaksesuaian antara kompetensi pegawai dengan tupoksi yang dilaksanakan. Terungkap juga problem perangkat kelurahan mencakup dua hal, yaitu:(1) terdapat ketidaksesuaian antara kemampuan yang dimiliki perangkat dengan kebutuhan pekerjaan dan (2) dari segi kuantitas ketersediaan sumber daya manusia juga masih dirasakan kurang oleh pihak kelurahan. Secara kuantitas, perangkat kelurahan yang dimiliki oleh kelurahan relatif bervariasi. Kelurahan Wadaslintang misalnya hanya memiliki 3 perangkat, Kelurahan Leksono mempunyai 4 perangkat dan Kelurahan Wonoroto memiliki 5 perangkat.

\section{Motif Usulan Perubahan Kelurahan Menjadi Desa}

Kemungkinan perubahan status pemerintah kelurahan menjadi pemerintahan desa dijamin oleh UU No 6 Tahun 2014 tentang Desa, seperti terlihat pada Pasal 12 yang menyatakan bahwa: (1) Pemerintah Daerah Kabupaten/Kota dapat mengubah status kelurahan menjadi Desa berdasarkan prakarsa masyarakat dan memenuhi persyaratan yang ditentukan sesuai dengan ketentuan peraturan perundang-undangan. (2) Kelurahan yang berubah status menjadi Desa, sarana dan prasarana menjadi milik Desa dan dikelola oleh Desa yang bersangkutan untuk kepentingan masyarakat Desa. (3) Pendanaan perubahan status kelurahan sebagaimana dimaksud pada ayat (1) dibebankan pada Anggaran Pendapatan dan Belanja Daerah Kabupaten/Kota.

Sedangkan dalam penjelasannya berbunyi sebagai berikut "Yang dimaksud dengan "mengubah status kelurahan menjadi Desa" adalah perubahan status kelurahan menjadi Desa atau kelurahan sebagian menjadi Desa dan sebagian tetap menjadi kelurahan. Hal tersebut dilakukan dalam jangka waktu tertentu untuk menyesuaikan adanya kelurahan yang kehidupan masyarakatnya masih bersifat perdesaan.

Merujuk pada peraturan tersebut, beberapa kelurahan di Kabupaten Wonosobo mengajukan pertimbangan perubahan status pemerintah Kelurahan menjadi Desa. Berdasarkan hasil diskusi kelompok terfokus dengan para informan, beberapa motif yang mendasari pertimbangan usulan tersebut adalah sebagai berikut: a) Alasan Ekonomi; Organisasi Kelurahan apabila berubah menjadi Desa merasa memiliki peluang lebih besar untuk mendapatkan sumber-sumber pendanaan bagi peningkatan kesjahteraan masyarakatnya. Dengan status "Desa" mereka merasa lebih leluasa untuk mampu menggaet dana-dana bagi desa baik dari propinsi maupun dari pusat. Apalagi dengan keluarnya Undang-undang No. 6 Tahun 2014, di mana desa mendapatkan sumber pendanaan dari pemerintah pusat yang berjumlah milyaran rupiah menjadi faktor pendorong utama lembaga kelurahan ingin berubah fungsi menjadi lembaga desa. b) Alasan Politis; Dengan status menjadi desa, mereka memiliki hak otonomi untuk mengelola sumber daya yang dimilikinya bagi peningkatan kesejahteraan masyarakatnya. Secara politis, mereka mempunyai kewenangan mengelola pembangunan di wilayahnya secara mandiri dari mulai tahap penyusunan perencanaan pembangunan desa (RAPBDes) hingga tahap implementasi. Untuk dapat membedakan secara lebih rinci antara Pemerintahan Kelurahan dengan Desa dapat dilihat pada tabel berikut: 
Tabel 2.

Perbedaan pemerintahan kelurahan dengan desa

\begin{tabular}{|c|c|c|c|}
\hline No. & Karakteristik & Kelurahan & Desa \\
\hline & Pengertian & $\begin{array}{l}\text { Pembagian wilayah administratif } \\
\text { di bawah kecamatan, wilayah } \\
\text { kerja Lurah merupakan bagian } \\
\text { dari wilayah kecamatan (bukan } \\
\text { merupakan SKPD) Kabupaten } \\
\text { atau kota. }\end{array}$ & $\begin{array}{l}\text { Kesatuan masyarakat hukum yang } \\
\text { memiliki batas-batas wilayah yang } \\
\text { berwenang untuk mengatur dan } \\
\text { mengurus kepentingan masyarakat } \\
\text { setempat, berdasarkan asal-usul } \\
\text { dan adat istiadat setempat yang } \\
\text { diakui dan dihormati dalam sistem } \\
\text { Pemerintahan NKRI }\end{array}$ \\
\hline & Letak & $\begin{array}{l}\text { Di kecamatan kota/ibu kota Kab/ } \\
\text { Kota. }\end{array}$ & $\begin{array}{l}\text { Di kecamatan di luar ibu Kota Kab/ } \\
\text { Kota }\end{array}$ \\
\hline & Pendanaan & $\begin{array}{l}\text { Dari APBD dan menjadi satu } \\
\text { dengan anggaran kecamatan. }\end{array}$ & Mempunyai APBDes tersendiri \\
\hline & Status Lembaga & $\begin{array}{l}\text { Bagian dari wilayah kecamatan } \\
\text { (bukan SKPD dan tidak otonom) }\end{array}$ & $\begin{array}{l}\text { Bukan perangkat dari Kab/Kota } \\
\text { (otonom) }\end{array}$ \\
\hline & Sifat lembaga & Administratif & Mempunyai Hak politik \\
\hline
\end{tabular}

\section{Letak geografis}

Status kelurahan di Wonosobo sebagian berada di daerah pedesaan, sehingga secara geografis mereka lebih layak disebut sebagai desa daripada kelurahan. Terbatasnya kelurahan dalam mengelola pembangunan membuat warga kelurahan merasa dianaktirikan dibandingkan dengan warga desa sekitar. Proses pembangunan di desa bisa dilakukan secara mandiri oleh perangkat desa dengan jumlah dana yang cukup. Sementara itu, proses pembangunan di kelurahan sangat tergantung pada kebijakan pemerintah kabupaten, itupun dengan jumlah dana yang terbatas.

\section{Profil masyarakat}

Dari sisi persyaratan suatu wilayah menjadi kelurahan, sebenarnya banyak kelurahan di Wonosobo belum memenuhi persyaratan dari aspek profil masyarakatnya. Berdasarkan peraturan Undang-undang No. 23 Tahun 2014 tentang Pemerintahan Daerah menyaratkan suatu wilayah menjadi kelurahan apabila ciri-ciri masyarakatnya bersifat heterogen dari sisi pendidikan, jenis pekerjaan yang dimiliki, lembaga ekonomi yang berkembang di wilayah tersebut seperti keberadaan pasar modern, lembaga perbangkan, sarana transportasi dan sejenisnya. Dalam kenyataannya, sebagian besar kelurahan di Wonosobo berkarakteristik seperti masyarakat pedesaan. Mereka lebih banyak hidup dari sektor pertanian, lembaga ekonomi yang berkembang lebih bersifat tradisional.

Berdasarkan hasil temuan studi, perubahan status kelembagaan kelurahan sebagai konsekuensi implementasi UU No. 23 Tahun 2014 tentang Pemerintahan Daerah telah membawa implikasi besar. Secara teoritik, pilihan model desentralisasi dapat berdampak positif terhadap efektivitas penyelanggaraan layanan publik. Namun demikian, menurut Abdullah (2013) efektivitas pelayanan publik mempersyaratkan kondisi internal organisasi yang stabil. Tanpa stabilitas yang kuat, maka akan sulit terwujud pelayanan publik yang baik. Apa yang terjadi di beberapa kelurahan di Kabupaten Wonosobo tengah menunjukkan gejala instabilitas. Berkembangnya usulan perubahan status kelembagaan kelurahan menjadi desa mencerminkan situasi internal kelurahan yang tidak stabil. Proses penetapan status kelurahan sebelumnya yang cenderung dipaksakan telah menjadi dasar bagi beberapa kelurahan untuk mengajukan perubahan status menjadi desa kembali. Apalagi dengan adanya UU No. 6 Tahun 2014 tentang Desa dimana pemerintahan desa mengalami penguatan anggaran, telah membuat beberapa kelurahan yang secara sosiologis masih bernuansa pedesaaan ingin mengembalikan status kelembagaan desa kembali. Bagi beberapa kelurahan tersebut, status 
kelembagaan saat ini telah membatasi fungsi kelurahan dalam melayani pelaksanaan pembangunan fisik. Dalam hal ini, penyediaan fasilitas umum dan sosial di lingkungan kelurahan dinilai belum dapat memenuhi kebutuhan dari masyarakat.

Temuan penting lainnya dari studi ini adalah kebijakan desentralisasi tidak mengantisipasi terjadinya ketimpangan kewenangan antara desa dan kelurahan. Padahal kedua lembaga tersebut bersentuhan langsung dengan warga masyarakat di level terbawah. Memang dalam UU No. 23 Tahun 2014 diakomodasi perubahan kelurahan menjadi desa, namun proses perubahan kelembagaan tersebut tentu membutuhkan waktu yang sangat lama dan penataan ulang kepemilikan aset dan status kepegawaian. Idealnya, desentralisasi juga berimplikasi pada penguatan kapasitas lembaga lokal (Boasiako 2010, Ribot 2002). Dalam hal ini, kapasitas kelurahan juga idealnya mengalami penguatan karena dituntut untuk menyelenggarakan pelayanan publik dan pembangunan. Publik di wilayah kelurahan tentu akan mengalami kerugian apabila kapasitas pemerintah kelurahan tidak mampu menjawab kebutuhan masyarakat.

Situasi paradok tercermin dari penguatan kapasitas pemerintah desa di satu pihak namun di pihak lain telah terjadi penyusutan kapasitas pemerintah kelurahan. Kondisi ini merupakan implikasi penting akibat implementasi UU No. 23 Tahun 2014 tentang Pemerintahan Daerah. Persoalan ini tentu akan menciptakan kesenjangan pelayanan publik antara desa dan kelurahan. Di satu sisi desa saat ini memperoleh status otonomi, sedangkan di pihak lain, kelurahan telah berubah menjadi lembaga yang tidak otonom. Dalam konteks ekonomi dan sosial, kelurahan yang masih mencerminkan wilayah pedesaan tentu tidak akan diuntungkan karena dinamika pembangunan di wilayahnya tidak lagi berdampak langsung terhadap perekonomian lokal. Aktivitas pembangunan sangat tergantung pada alokasi yang ditetapkan pihak kecamatan. Pada akhirnya, seperti yang dikemukakan oleh Selle (2006), desentralisasi yang harapannya dapat meningkatkan kinerja pemerintahan lokal, dalam realisasinya dapat menciptakan sedikit insentif dalam pengembangan responsivitas dan akuntabilitas. Dalam konteks penelitian di Wonosobo, desentralisasi justru menciptakan disensentif bagi beberapa pemerintah kelurahan yang secara geografis dan sosiologis masih merupakan wilayah perdesaan. Akibat kebijakan baru desentralisasi, kelembagaan kelurahan tidak mendapatkan penguatan tetapi justru mengalami penyusunan otoritas. Situasi ini menjadi paradok jika dibandingkan dengan yang terjadi pada pemerintah desa.

\section{Simpulan}

Implementasi kebijakan desentralisasi melalui UU No 23 Tahun 2014 tentang Pemerintahan Daerah telah memberikan dampak besar terhadap status kelembagaan kelurahan. Sebelumnya, kelurahan memiliki kewenangan untuk menyusun perencanaan. Sejak tahun 2015, pemerintah kelurahan tidak lagi menjadi organisasi perangkat daerah yang mandiri tetapi telah menjadi bagian dari pemerintah kecamatan. Konsekuensinya, kegiatan-kegiatan yang dilaksanakan pemerintah kelurahan ditentukan oleh kebijakan yang diputuskan oleh pemerintah kecamatan. Kinerja pelaksanaan pembangunan fisik di tingkat kelurahan berada pada level rendah. Situasi ini tentu tidak menguntungkan masyarakat di wilayah kelurahan. Harapannya, perubahan kebijakan desentralisasi dapat semakin menguatkan kelembagaan kelurahan. Namun dalam realisasinya, kelurahan justru menjadi lembaga yang harus menerima biaya politik dalam bentuk pengurangan kewenangan dan anggaran pembangunan pasca implementasi UU No 23 Tahun 2014. Dalam kasus ini, ketiga kelurahan yang berkarakter desa baik secara geografis maupun sosiologis tidak dapat menyediakan fasilitas umum dan sosial yang diharapkan masyarakat. Situasi ini bertolak belakang dengan Pemerintah Desa yang didukung dengan dana desa yang besar dapat melakukan aktivitas pembangunan fisik lebih baik daripada ketiga kelurahan tersebut. Dengan demikian, secara kelembagaan fungsi dan tugas kelurahan menjadi lebih banyak berkurang daripada pemerintah desa.

Perubahan kelembagaan kelurahan pasca implementasi UU No 23 Tahun 2014 telah mendorong beberapa kelurahan di Kabupaten Wonosobo seperti Wonoroto, Wadaslintang dan Leksono untuk mengusulkan perubahan kelembagaan kelurahan menjadi Desa. Selain faktor historis dan geografis, 
faktor insentif ekonomi yang dinikmati oleh pemerintah desa dengan adanya kebijakan dana desa telah memotivasi ketiga kelurahan tersebut mengajukan pengembalian status pemerintahannya. Dalam pandangan mereka, pengurangan kewenangan pemerintahan kelurahan berpengaruh besar terhadap kelangsungan aktivitas pembangunan di wilayah kelurahan. Sementara itu, kondisi sosiologis masyarakat yang dilayani oleh ketiga kelurahan tersebut adalah masyarakat desa sehingga berkembang kekhawatiran bahwa masyarakat di tiga kelurahan tersebut tidak mendapatkan pelayanan yang lebih baik daripada sebelumnya.

Oleh karena itu, penelitian ini merekomendasikan di masa yang akan datang upaya-upaya untuk menguatkan lembaga kelurahan perlu dipertimbangkan oleh pemerintah. Penguatan terhadap lembaga kelurahan dapat dilakukan dengan kebijakan-kebijakan antara lain: Pemberdayaan masyarakat dan lembaga-lembaga masyarakat, Pemberdayaan aparatur lembaga kelurahan, pemberian kewenangan yang lebih besar kepada lembaga kelurahan untuk penggalian dan pemanfaatan sumber daya alam, bagi hasil dari retribusi dari PBB, Galian Golongan C dan Ijin Gangguan (HO) sesuai dengan potensi kelurahan masing-masing, pembentukan Badan Usaha Milik Kelurahan (BUMKel), pengisian jabatan fungsional kelurahan antara lain jabatan bidang kesehatan lingkungan, pertanahan dan bidang kesejahteraan rakyat.

\section{Ucapan Terima Kasih}

Peneliti mengucapkan terima kasih kepada Lembaga Penelitian dan Pengabdian kepada Masyarakat (LPPM) Universitas Jenderal Soedirman yang telah memfasilitasi pembiayaan riset unggulan pada Tahun Anggaran 2016. Terima kasih juga disampaikan kepada semua pihak khususnya Bagian Pemerintahan Pemerintah Kabupaten Wonosobo yang telah membantu memfasilitasi data dan perizinan penelitian.

\section{Daftar Pustaka}

Anonim (2015) Demo, warga minta desa dikembalikan. http://www.radarkedu.com/wonosobo/ demo-warga-minta-desa-dikembalikan.

Abdullah MT (2013) Desentralisasi dan efektivitas pemerintahan daerah kabupaten maros. Masyarakat, Kebudayaan dan Politik 26 (2):108-118.

Boasiako KBA (2010) Public administration: Local government and decentralization in Ghana. Journal of African Studies and Development 2 (7): 166-175.

Ezcurra R (2015) Fiscal Decentralization and Internal Conflict: An Empirical Investigation. Environment and Planning C: Government and Policy 33 (3):580-600.

Garcia VR, Vincent V, Jorge A, Tomas H \& Pamela J (2010) The uneven reach of decentralization: a case study among indigenous peoples in the Bolivian Amazon. International Political Science Review 31 (2):229-243.

Lessmann C (2009) Fiscal decentralization and regional disparity: evidence from cross-section and panel data. Environment and Planning A 41 (10): 2455-2473.

Milles BM, Huberman AM \& Saldana J (2014) Qualitative Data Analysis, A Methode Sourcebook. USA: Sage Publication. Inc.

Ribot J (2002) Democratic Decentralization of Natural Resources: Institutionalizing popular participation. World Resource Institute.

Sanginga P, Kamugisha R \& Martin A (2010) Strengthening social capital for adaptive governance of natural resources: a participatory learning and action research for bylaws reforms in Uganda. Society and Natural Resources 23 (8): 695-710.

Selle AD (2006) The Paradox of Local Empowerment: Decentralization and Democratic Governance in Mexico. University of Maryland, College Park, ProQuest Dissertations Publishing.

Tang M \& Nuhe N (2015) The variant effect of decentralization on trust in national and local governments in Asia. Political Studies 64(1):216-234.

Van Zyil J, Barbosa T, Parker AN \& Sonn L (1995) Decentralized Rural Development and Enhanced Community Participation. Policy Working Paper No. 1498, World Bank, Washington, DC. 